\title{
Five New Guanacastane-Type Diterpenes from Cultures of the Fungus Psathyrella candolleana
}

\author{
Xia Yin · Tao Feng $\cdot$ Zheng-Hui Li $\cdot$ \\ Ying Leng $\cdot$ Ji-Kai Liu
}

Received: 3 April 2014/ Accepted: 21 April 2014/Published online: 8 May 2014

(C) The Author(s) 2014. This article is published with open access at Springerlink.com

\begin{abstract}
Five new guanacastane-type diterpenes, named guanacastepenes P-T (1-5), were isolated from cultures of the fungus Psathyrella candolleana. Their structures were elucidated on the basis of extensive spectroscopic methods. All of the compounds were tested for their $11 \beta$-hydroxysteroid dehydrogenase (11 $\beta$-HSD1) inhibitory activity. Compound 3 exhibited inhibitory activity against both human and mouse isozymes of $11 \beta$-HSD1 with $\mathrm{IC}_{50}$ values of 6.2 and $13.9 \mu \mathrm{M}$, respectively.
\end{abstract}

Keywords Psathyrella candolleana $\cdot$ Psathyrellaceae diterpenes $\cdot$ Guanacastepenes P-T $\cdot 11 \beta$-HSD1

\section{Introduction}

Guanacastepene A, was the first member of the guanacastane family isolated from an unidentified endophytic fungus (CR 115) [1]. This was followed by isolation of guanacastepenes B-O from the same fungus by the same group [2]. Heptemerones $A-G$ were later isolated from cultures of Coprinus heptemerus [3, 4], as well as radianspenes A-M from Coprinus radians [5], which attracted

Electronic supplementary material The online version of this article (doi:10.1007/s13659-014-0020-8) contains supplementary material, which is available to authorized users.

X. Yin · T. Feng · Z.-H. Li · J.-K. Liu ( $ه)$

State Key Laboratory of Phytochemistry and Plant Resources in

West China, Kunming Institute of Botany, Chinese Academy of

Sciences, Kunming 650201, People's Republic of China

e-mail: jkliu@mail.kib.ac.cn

$X$. Yin

University of Chinese Academy of Sciences, Beijing 100049,

People's Republic of China

Y. Leng

Shanghai Institute of Materia Medica, Chinese Academy of

Sciences, Shanghai 201203, People's Republic of China interest of the guanacastanes in the synthetic organic community [6-18]. The total synthesis of guanacastepenes with a novel 5/7/6 ring system was considered a challenging synthetic target [19], whereas synthesis of analogues offered the best prospects for capitalizing on the promising antibiotic activity, as well as avoiding the side effect of hemolytic activity against human red blood cells $[10,20]$. However, no other bioactivities, except for antibiotic effects were reported for this type of diterpenes. As a part of a search for naturally occurring secondary metabolites with diverse structures from higher fungi in China, investigations of chemical components from Psathyrella candolleana cultures were carried out, which led to the isolation of a series of new guanacastane-type diterpenes, guanacastepenes P-T (1-5, Fig. 1). Their structures were elucidated by means of spectroscopic methods. These compounds shared a larger conjugated system including an $\alpha, \beta$-unsaturated ketone moiety in the highly oxygenated five-member ring system comparing to the known guanacastane-type diterpenes. All of these compounds were evaluated for their cytotoxic and antiherpes simplex viruses (HSV) activities, while compounds $\mathbf{1}, \mathbf{3}$, and $\mathbf{5}$ were evaluated for inhibitory activities against one isozyme of $11 \beta$-hydroxysteroid dehydrogenases $(11 \beta$ HSD1). 

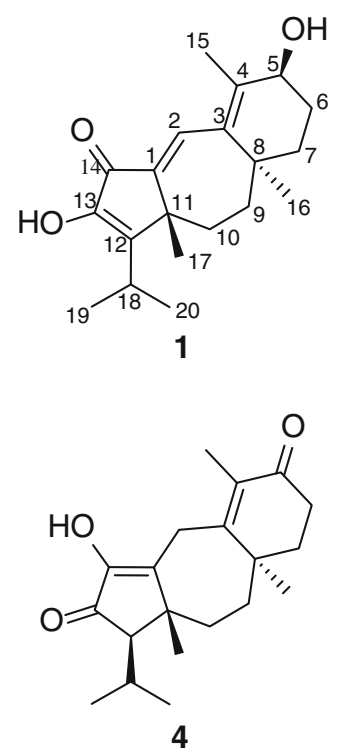

4

Fig. 1 Structures of compounds (1-5)

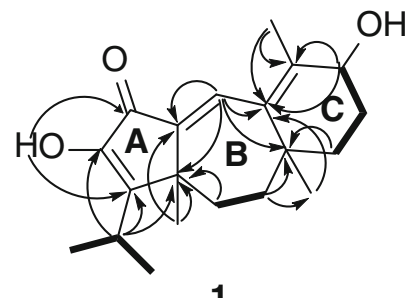

1
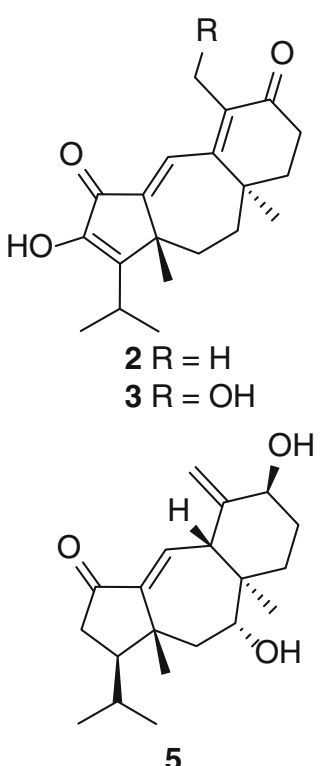

5

\section{- ${ }^{1} \mathrm{H}-{ }^{1} \mathrm{H}$ COSY \\ H C̀ HMBC}

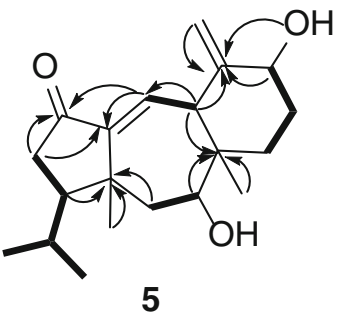

Fig. $2{ }^{1} \mathrm{H}-{ }^{1} \mathrm{H}$ COSY and HMBC correlations for $\mathbf{1}$ and $\mathbf{5}$

\section{Results and Discussion}

Guanacastepene $\mathrm{P}(\mathbf{1})$ was obtained as a light yellow oil. Its molecular formula $\mathrm{C}_{20} \mathrm{H}_{28} \mathrm{O}_{3}$ was established from the positive ion HRESIMS $\left([\mathrm{M}+\mathrm{Na}]^{+}, 339.1930\right)$, indicating 7 degrees of unsaturation. The ${ }^{13} \mathrm{C}$ NMR (DEPT) spectrum suggested 20 carbon resonances (Table 2), classified as five methyl groups, four aliphatic methylenes, three methines (one olefinic and one oxygenated), and eight quaternary carbons (one carbonyl and five olefinic). Thus, four degrees of unsaturation were accounted for by the three double bonds and the one carbonyl group, while the remaining three degrees of unsaturation suggested that compound $\mathbf{1}$ should possess a three-ring system. Further inspection of the ${ }^{1} \mathrm{H}$ NMR spectrum and ${ }^{1} \mathrm{H}-{ }^{1} \mathrm{H}$ COSY correlations (Fig. 2) resulted in the deduction of an isopropyl group (Me-19-H-18-Me-20), two connected methylene groups $\left(\mathrm{H}_{2}-9-\mathrm{H}_{2}-10\right)$, a chain of $\mathrm{CH}_{2}-\mathrm{CH}_{2}-\mathrm{CH}-\mathrm{OH}\left(\mathrm{H}_{2}-7-\mathrm{H}_{2}-6-\right.$
$\mathrm{H}-5-\mathrm{OH})$, an isolated olefinic hydrogen $(\mathrm{H}-2)$, and three isolated methyl groups (H-15, H-16 and H-17).

Connectivity among the above mentioned fragments and the contribution of the three-ring system were established by analysing ${ }^{1} \mathrm{H},{ }^{13} \mathrm{C}$ long-range correlations extracted from $\mathrm{HMBC}$ experiments (Fig. 2). The correlations of $\mathrm{H}-18$ to $\mathrm{C}-11, \mathrm{C}-12$ and $\mathrm{C}-13$ and HO-13 to C-12 and C-14 established the connection of C-11-C-12-C-13-C-14, while the correlations of $\mathrm{H}-17$ to $\mathrm{C}-11, \mathrm{C}-12$ and $\mathrm{C}-1$, and $\mathrm{H}-2$ to $\mathrm{C}-1$ and $\mathrm{C}-11$ indicated the presence of a fivemembered ring A. Subsequently, the correlations of $\mathrm{H}-9$ to C-8 and $\mathrm{H}-10$ to $\mathrm{C}-11$ supported the connection of C-8-C9-C-10-C-11. Besides, correlations of $\mathrm{H}-16$ to $\mathrm{C}-8$ and $\mathrm{C}-3$, as well as $\mathrm{H}-2$ to $\mathrm{C}-8$ were evident for a sevenmembered ring $\mathrm{B}$. The last ring $\mathrm{C}$ and the links of remaining blocks were clearly shown by $\mathrm{HMBC}$ correlations of $\mathrm{H}-15$ to C-3, C-4 and C-5, H-5 to C-4 and C-6, H-6 to $\mathrm{C}-4$ and $\mathrm{C}-5$, and $\mathrm{H}-7$ to $\mathrm{C}-8$ and $\mathrm{C}-3$. Finally, compound 1 possessed a backbone of a 5/7/6 ring system related to that of guanacastepene A [1]. Biogenetically, the stereoconfigurations of methyls of Me-16 and Me-17 were $\alpha$ and $\beta$ oriented, respectively [4]. In the ROESY spectrum (Fig. 3 ), correlations between $\mathrm{H}-17, \mathrm{H}-9 \beta$ and $\mathrm{H}-10 \beta$ were observed, suggesting both were $\beta$ oriented, while correlations of $\mathrm{H}-5 / \mathrm{H}-6 \alpha$, and $\mathrm{H}-6 \alpha / \mathrm{H}-16$ indicated that $\mathrm{H}-5$ was $\alpha$ oriented.

Guanacastepene Q (2), purified as a light yellow oil, had a molecular formula of $\mathrm{C}_{20} \mathrm{H}_{26} \mathrm{O}_{3}$ according to its HRESIMS at $\left.m / z 315.1962([\mathrm{M}+\mathrm{H}]]^{+}\right)$. The ${ }^{13} \mathrm{C}$ NMR (Table 2) spectroscopic data were similar to those of compound $\mathbf{1}$. The main difference was that an oxygenated methine at $\delta_{\mathrm{C}}$ $70.3(\mathrm{C}-5)$ in 1 was replaced by a keto carbonyl group at $\delta_{\mathrm{C}}$ 197.5 in 2, constructing a 3,4-unsaturated-5-keto moiety, which led to the downfield shift of C-3 $(\Delta \delta 20.8 \mathrm{ppm})$ and C-6 ( $\Delta \delta \quad 4.4 \mathrm{ppm})$, and the upfield shift of C-4 $(\Delta \delta$ $6.4 \mathrm{ppm}$ ) in compound 2 , consistent with the HMBC correlations of H-6, H-7 and $\mathrm{H}-15$ to $\mathrm{C}-5$. Detailed analysis of 1D and 2D NMR data (HSQC, HMBC, ${ }^{1} \mathrm{H}-{ }^{1} \mathrm{H}$ COSY, ROESY) suggested that the other parts of 2 were the same as those of $\mathbf{1}$. Therefore, compound $\mathbf{2}$ was established as shown.

Guanacastepene R (3), a light yellow oil, had a molecular formula of $\mathrm{C}_{20} \mathrm{H}_{26} \mathrm{O}_{4}$ on the basis of its HRESIMS at $\mathrm{m} / \mathrm{z} 353.1737\left([\mathrm{M}+\mathrm{Na}]^{+}\right), 16$ mass units higher than that of 2. The 1D NMR spectroscopic data (Tables 1 and 2) were quite similar to those of $\mathbf{2}$, except that the signals for a methyl group in $\mathbf{2}$ were replaced by the signals for an oxygenated methylene group, which was confirmed by the HMBC correlations of $\delta_{\mathrm{H}} 3.62(1 \mathrm{H}, \mathrm{d}, J=7.0 \mathrm{~Hz}, \mathrm{OH}-15)$ to $\delta_{\mathrm{C}} 56.4(\mathrm{t}, \mathrm{C}-15)$ and $\delta_{\mathrm{C}} 136.3(\mathrm{~s}, \mathrm{C}-4)$. Careful analysis of the spectroscopic data finally established the structure of $\mathbf{3}$ as guanacastepene $\mathrm{R}$, as shown. 
Table $1{ }^{1} \mathrm{H}$ NMR $\left[\delta_{\mathrm{H}}\right.$ (mult, $\left.\left.J(\mathrm{~Hz})\right)\right]$ spectroscopic data $(400 \mathrm{MHz})$ for guanacastepenes P-T (1-5)

\begin{tabular}{|c|c|c|c|c|c|}
\hline No. & $\mathbf{1}^{\mathrm{a}}$ & $2^{\mathrm{a}}$ & $3^{\mathrm{a}}$ & $4^{a}$ & $5^{\mathrm{b}}$ \\
\hline \multicolumn{6}{|l|}{1} \\
\hline 2 & 6.90 , br. s & 6.96 , br. s & 7.17, s & $\begin{array}{l}3.50, \mathrm{~d}(19.0) \\
3.66, \mathrm{~d}(19.0)\end{array}$ & $6.85, \mathrm{~d}(4.1)$ \\
\hline 3 & & & & & 3.43 , br. s \\
\hline 5 & $4.02, \mathrm{~m}$ & & & & $4.42, \mathrm{~m}$ \\
\hline $6 \alpha$ & $1.91, \mathrm{~m}$ & $2.35, \mathrm{dt}(16.8,4.8)$ & $2.37, \mathrm{dt}(16.7,4.9)$ & $2.35, \mathrm{dt}(17.1,4.7)$ & $1.72, \mathrm{~m}$ \\
\hline $6 \beta$ & $1.75, \mathrm{~m}$ & 2.68, ddd $(16.8,13.1,4.8)$ & 2.69, ddd $(16.7,13.2,4.9)$ & $2.61, \mathrm{~m}^{\mathrm{c}}$ & $1.85, \mathrm{~m}^{\mathrm{c}}$ \\
\hline $7 \alpha$ & 1.66, ddd $(13.5,7.4,2.8)$ & $2.02, \mathrm{~m}$ & $2.03, \mathrm{~m}$ & 1.82 , overlapped & $1.84, \mathrm{~m}$ \\
\hline $7 \beta$ & 1.51 , overlapped & $1.90, \mathrm{~m}$ & $1.92, \mathrm{~m}$ & $1.89, \operatorname{td}(13.1,4.7)$ & \\
\hline $9 \alpha$ & 1.45, ddd $(14.0,4.4,3.3)$ & $1.59, \mathrm{dt}(14.4,3.1)$ & 1.62, ddd $(14.3,4.4,3.1)$ & 1.80, overlapped & 3.89, br.d (11.6) \\
\hline $9 \beta$ & $2.21, \operatorname{td}(14.0,3.3)$ & 2.47, td $(14.4,3.1)$ & $2.48, \operatorname{td}(14.0,3.1)$ & $1.60, \operatorname{td}(13.9,3.5)$ & \\
\hline $10 \alpha$ & $1.54, \operatorname{td}(14.0,3.3)$ & $1.73, \operatorname{td}(13.6,3.1)$ & $1.75, \operatorname{td}(13.8,3.1)$ & $2.14, \mathrm{~m}$ & $2.16, \mathrm{~m}$ \\
\hline $10 \beta$ & 1.84 , ddd $(14.0,4.4,3.3)$ & 1.94 , overlapped & 1.95 , overlapped & $1.46, \mathrm{~m}^{\mathrm{c}}$ & 1.74, overlapped $^{\mathrm{c}}$ \\
\hline 12 & & & & $1.97, \mathrm{~d}(2.7)$ & 1.57 , overlapped \\
\hline 13 & & & & & 2.47 , dd $(18.1,7.6)$ \\
\hline & & & & & $2.14, \mathrm{~m}$ \\
\hline 15 & $1.72, \mathrm{~s}$ & $1.67, \mathrm{~s}$ & 4.26, dd $(11.9,5.9)$ & 1.84 , br.s & $5.22, \mathrm{~d}(1.4)$ \\
\hline & & & 4.11 , dd $(11.9,5.9)$ & & $5.11, \mathrm{~d}(1.4)$ \\
\hline 16 & $0.86, \mathrm{~s}$ & $1.07, \mathrm{~s}$ & $1.10, \mathrm{~s}$ & $1.11, \mathrm{~s}$ & $0.66, \mathrm{~s}$ \\
\hline 17 & $1.12, \mathrm{~s}$ & $1.12, \mathrm{~s}$ & $1.15, \mathrm{~s}$ & $1.11, \mathrm{~s}$ & $1.16, \mathrm{~s}$ \\
\hline 18 & $2.52, \mathrm{~h}(7.0)$ & $2.54, \mathrm{~h}(7.1)$ & $2.55, \mathrm{~h}(7.0)$ & $2.07, \mathrm{~m}$ & $1.82, \mathrm{~m}$ \\
\hline $19^{\mathrm{d}}$ & $1.26, \mathrm{~d}(7.0)$ & $1.30, \mathrm{~d}(7.1)$ & $1.30, \mathrm{~d}(7.0)$ & $1.14, \mathrm{~d}(6.9)$ & $0.93, \mathrm{~d}(6.7)$ \\
\hline $20^{\mathrm{d}}$ & $1.29, \mathrm{~d}(7.0)$ & $1.28, \mathrm{~d}(7.1)$ & $1.28, \mathrm{~d}(7.0)$ & $0.84, \mathrm{~d}(6.9)$ & $1.07, \mathrm{~d}(6.7)$ \\
\hline $5-\mathrm{OH}$ & $3.98, \mathrm{~d}(6.7)$ & & & & \\
\hline $13-\mathrm{OH}$ & 7.71, br. s & 7.91 , br. s & 7.96 , br. s & & \\
\hline $14-\mathrm{OH}$ & & & & 7.84 , br. s & \\
\hline $15-\mathrm{OH}$ & & & $3.62, \mathrm{t}(5.9)$ & & \\
\hline
\end{tabular}

${ }^{\mathrm{a}} \mathrm{In} \mathrm{Me}_{2} \mathrm{CO}-d_{6}$

b In $\mathrm{CDCl}_{3}$

c Could not be assigned to $\alpha / \beta$, signals overlapping

d Signals were exchangeable

Guanacastepene S (4) had the same molecular formula of $\mathrm{C}_{20} \mathrm{H}_{28} \mathrm{O}_{3}$ (HRESIMS ([M+Na] $]^{+}$at $m / z$ 339.1927) as $\mathbf{1}$ and was obtained as a colorless oil. Its ${ }^{13} \mathrm{C}$ NMR spectrum (Table 2) displayed 20 carbon signals corresponding to five methyls (three singlets and two doublets), five methylenes, two methines and eight quaternary carbons (four olefinic and two carbonyl carbons), consistent with a similar structure of compound 2. Significant differences were one less double bond and absence of an olefinic hydrogen in $\mathbf{4}$. The $\mathrm{H}-18$ correlation with a methine proton at $\delta_{\mathrm{H}} 1.97(1 \mathrm{H}$, $\mathrm{d}, J=2.7 \mathrm{~Hz}, \mathrm{H}-12)$ in the ${ }^{1} \mathrm{H}-{ }^{1} \mathrm{H}$ COSY spectrum, and the key HMBC correlations of the $\mathrm{OH}$ signal at $\delta_{\mathrm{H}} 7.84(1 \mathrm{H}$, br. s, OH-14) to a keto carbonyl carbon $\delta_{\mathrm{C}} 202.9$ (s, C-13) and the double bond signal at $\delta_{\mathrm{C}} 148.1$ (s, C-14) indicated a different enolization of the 13,14-diketone system (to a 13-keto-14-enol) in 4. Further analysis of 2D NMR spectroscopic data suggested that the other parts were the same to those of $\mathbf{2}$, except the olefinic carbon at $\mathrm{C}-2$ in $\mathbf{2}$ being replaced by a methylene moiety in $\mathbf{4}$, as established by the HMBC correlations of $\delta_{\mathrm{H}} 3.50$ and 3.60 (each $1 \mathrm{H}, \mathrm{d}, J=$ $19.0 \mathrm{~Hz}, \mathrm{H}-2)$ to $\mathrm{C}-1$. On the basis of the ROESY experiment, $\mathrm{H}-12$ was elucidated to be $\alpha$ oriented by correlations of $\mathrm{H}-17$ with $\mathrm{H}-18$ and $\mathrm{H}-19$. Thus compound 4 was assigned as guanacastepene $\mathrm{S}$.

Guanacastepene $\mathrm{T}(\mathbf{5})$ possessed the molecular formula $\mathrm{C}_{20} \mathrm{H}_{30} \mathrm{O}_{3}$, as determined by its HRESIMS at $\mathrm{m} / \mathrm{z}, 341.2091$ $\left([\mathrm{M}+\mathrm{Na}]^{+}\right)$, indicating six degrees of unsaturation. The ${ }^{13} \mathrm{C}$ NMR spectroscopic data (Table 2) together with analysis of its HSQC spectrum indicated 20 carbons, including four methyls, five methylenes (one olefinic), six methines (two oxygenated and one olefinic), and five quaternary carbons (two olefinic and one carbonyl carbons). Comprehensive analysis of the ${ }^{1} \mathrm{H}-{ }^{1} \mathrm{H}$ COSY and $\mathrm{HMBC}$ spectra (Fig. 2), suggested that $\mathbf{5}$ shared the same 
Table $2{ }^{13} \mathrm{C}$ NMR data of guanacastepenes $\mathrm{P}-\mathrm{T}$ (1-5)
${ }^{\text {a }}$ Recorded at $150 \mathrm{MHz}$ in $\mathrm{Me}_{2} \mathrm{CO}-d_{6}$

${ }^{\mathrm{b}}$ Recorded at $100 \mathrm{MHz}$ in $\mathrm{Me}_{2} \mathrm{CO}-d_{6}$

${ }^{c}$ Recorded at $150 \mathrm{MHz}$ in $\mathrm{CDCl}_{3}$

d Signals were exchangeable

\begin{tabular}{|c|c|c|c|c|c|}
\hline No. & $\mathbf{1}^{\mathrm{a}}$ & $2^{\mathrm{b}}$ & $3^{\mathrm{a}}$ & $4^{a}$ & $5^{\mathrm{c}}$ \\
\hline 1 & 141.6, qC & $142.3, \mathrm{qC}$ & 143.1, qC & $148.8, \mathrm{qC}$ & $147.5, \mathrm{qC}$ \\
\hline 2 & $130.4, \mathrm{CH}$ & $127.9, \mathrm{CH}$ & $127.3, \mathrm{CH}$ & $30.3, \mathrm{CH}_{2}$ & $134.2, \mathrm{CH}$ \\
\hline 3 & $136.4, \mathrm{qC}$ & 157.2, qC & $160.4, \mathrm{qC}$ & $160.5, \mathrm{qC}$ & $40.5, \mathrm{CH}$ \\
\hline 4 & $139.1, \mathrm{qC}$ & 132.7, qC & $136.3, \mathrm{qC}$ & $131.8, \mathrm{qC}$ & 148.6, qC \\
\hline 5 & $70.3, \mathrm{CH}$ & $197.5, \mathrm{qC}$ & $198.0, \mathrm{qC}$ & 197.5, qC & $73.9, \mathrm{CH}$ \\
\hline 6 & 29.7, $\mathrm{CH}_{2}$ & $34.1, \mathrm{CH}_{2}$ & $34.3, \mathrm{CH}_{2}$ & $34.2, \mathrm{CH}_{2}$ & $30.0, \mathrm{CH}_{2}$ \\
\hline 7 & $38.0, \mathrm{CH}_{2}$ & $38.9, \mathrm{CH}_{2}$ & $38.9, \mathrm{CH}_{2}$ & $39.9, \mathrm{CH}_{2}$ & $31.5, \mathrm{CH}_{2}$ \\
\hline 8 & 36.7, qC & $37.5, \mathrm{qC}$ & $37.8, \mathrm{qC}$ & $40.2, \mathrm{qC}$ & $44.3, \mathrm{qC}$ \\
\hline 9 & $38.5, \mathrm{CH}_{2}$ & $35.5, \mathrm{CH}_{2}$ & $35.5, \mathrm{CH}_{2}$ & $41.3, \mathrm{CH}_{2}$ & $77.2, \mathrm{CH}$ \\
\hline 10 & $30.9, \mathrm{CH}_{2}$ & $30.7, \mathrm{CH}_{2}$ & $30.8, \mathrm{CH}_{2}$ & $36.1, \mathrm{CH}_{2}$ & 43.7, $\mathrm{CH}_{2}$ \\
\hline 11 & $44.7, \mathrm{qC}$ & 44.6, qC & $44.7, \mathrm{qC}$ & $45.0, \mathrm{qC}$ & $44.0, \mathrm{qC}$ \\
\hline 12 & $154.9, \mathrm{qC}$ & $155.7, \mathrm{qC}$ & $155.9, \mathrm{qC}$ & $62.0, \mathrm{CH}$ & $51.8, \mathrm{CH}$ \\
\hline 13 & 151.0, qC & 151.2, qC & 151.3, qC & 202.9, qC & 41.3, $\mathrm{CH}_{2}$ \\
\hline 14 & $189.1, \mathrm{qC}$ & $188.5, \mathrm{qC}$ & $188.5, \mathrm{qC}$ & $148.1, \mathrm{qC}$ & 205.2, qC \\
\hline 15 & 17.0, $\mathrm{CH}_{3}$ & $12.2, \mathrm{CH}_{3}$ & $56.4, \mathrm{CH}_{2}$ & $11.7, \mathrm{CH}_{3}$ & $111.9, \mathrm{CH}_{2}$ \\
\hline 16 & 26.5, $\mathrm{CH}_{3}$ & 26.1, $\mathrm{CH}_{3}$ & $25.9, \mathrm{CH}_{3}$ & $24.3, \mathrm{CH}_{3}$ & $10.5, \mathrm{CH}_{3}$ \\
\hline 17 & $20.7, \mathrm{CH}_{3}$ & 20.6, $\mathrm{CH}_{3}$ & $20.8, \mathrm{CH}_{3}$ & $17.8, \mathrm{CH}_{3}$ & 17.2, $\mathrm{CH}_{3}$ \\
\hline 18 & $26.5, \mathrm{CH}$ & $26.5, \mathrm{CH}$ & 26.6, CH & $28.1, \mathrm{CH}$ & $28.7, \mathrm{CH}$ \\
\hline $19^{\mathrm{d}}$ & $20.8, \mathrm{CH}_{3}$ & $20.7, \mathrm{CH}_{3}$ & $20.7, \mathrm{CH}_{3}$ & 23.7, $\mathrm{CH}_{3}$ & 22.6, $\mathrm{CH}_{3}$ \\
\hline $20^{\mathrm{d}}$ & $20.8, \mathrm{CH}_{3}$ & $20.7, \mathrm{CH}_{3}$ & $20.7, \mathrm{CH}_{3}$ & $19.2, \mathrm{CH}_{3}$ & $24.3, \mathrm{CH}_{3}$ \\
\hline
\end{tabular}
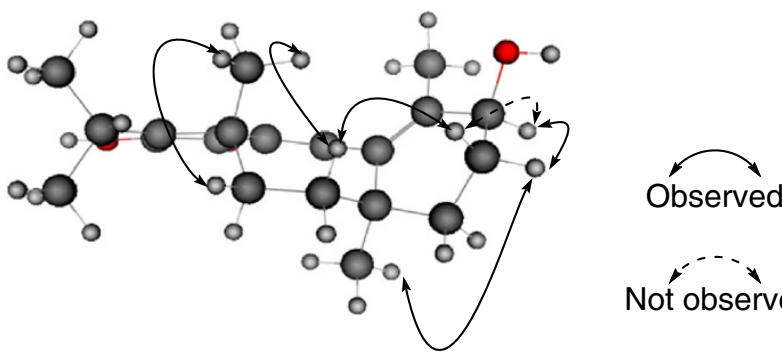

Not observed

Fig. 3 Key ROESY correlations of 1

$40 \mu \mathrm{M}$. In addition, they were evaluated for anti-HSV (herpes simplex viruses) activity. However, none exhibited activity. Furthermore, compounds 1, $\mathbf{3}$ and $\mathbf{5}$ were tested for inhibitory activities against one isozyme of $11 \beta$-HSD1. Of these, only compound $\mathbf{3}$ exhibited inhibitory activity against both human and mouse isozymes of $11 \beta$-HSD1 with $\mathrm{IC}_{50}$ values of 6.2 and $13.9 \mu \mathrm{M}$, while glycyrrhizinic acid (positive control) had $\mathrm{IC}_{50}$ values of 4.2 and $6.5 \mathrm{nM}$, respectively.

Five new guanacastane-type diterpenes, guanacastepenes $\mathrm{P}-\mathrm{T}$, each containing a 5/7/6 ring system, were isolated from cultures of fungus $P$. candolleana. Until now, totally 33 guanacastane-type diterpenes have been obtained from kinds of fungi, and some of them showed antibiotic and antitumor activities. Our present research enriched the structure diversity of the guanacastane family and this is 
also the first report to show that guanacastane-type diterpenes possessed inhibitory activity against human $11 \beta$ HSD1.

\section{Experimental}

\subsection{General Experimental Procedures}

Optical rotations (OR) were recorded on a JASCO P-1020 digital polarimeter, while the UV and IR spectra were obtained on a Shimadzu UV2401PC and a Bruker Tensor 27 FT-IR ( $\mathrm{KBr}$ pellets) spectrometers. NMR spectra were acquired on Bruker AM-400, DRX-500 and Avance III $600 \mathrm{MHz}$ spectrometers with tetramethylsilane (TMS) used as an internal standard at room temperature. Highresolution (HR) ESI-MS were recorded on an API QSTAR Pulsar spectrometer. Silica gel (200-300 mesh, Qingdao Marine Chemical Ltd., People's Republic of China) and Sephadex LH-20 (Amersham Biosciences, Sweden) were used for open column chromatography (CC). Preparative HPLC was performed on an Agilent 1100 liquid chromatography system equipped with a Zorbax SB-C18 column $(21.2 \mathrm{~mm} \times 150 \mathrm{~mm})$. Fractions were monitored by TLC. Spots were visualized by heating silica gel plates immersed in vanillin- $\mathrm{H}_{2} \mathrm{SO}_{4}$ in $\mathrm{EtOH}$.

\subsection{Fungal Material and Cultivation Conditions}

The fungus $P$. candolleana (Pers.) Fr. was collected at Kunming Institute of Botany in Yunnan Province, People's Republic of China, in 2003. The fungus was identified by Prof. Zhu-Liang Yang at the Kunming Institute of Botany. A specimen (No. KIB20030828) was deposited at Kunming Institute of Botany, Chinese Academy of Sciences.

Basidiomata small to medium-sized. Pileus $3-7 \mathrm{~cm}$ in diam, campaniform then flattened, with moist umbonate center; surface glabrous, light honey-yellow to brown, yellow-brown at the apex, fading to grayish when dry; white universal veil gradually fall off with age. Context white, relatively thin. Lamellae adnate, narrow and length unequal, crowded, dirty white, grayish to pallid purplebrown; edge dirty white, coarse. Stipe slender and fistulous, cylindrical, 3-8 $\times 0.2-0.7 \mathrm{~cm}$, white, weak and fragile, surface densely floccose-fibrillose or reticulate. Spores print dark purple-brown; spores smooth, ellipsoid, 6.5-9.0 $\times 3.5-5.0 \mu \mathrm{m}$, germ pore was visible. Pleurocystidia smooth and thin-walled, hyaline in $\mathrm{KOH}$, more or less lageniform and apex rounded, 34-50 × 8-16 $\mu \mathrm{m}$.

The culture medium consisted of glucose $(5 \%)$, peptone from porcine meat $(0.15 \%)$, yeast powder $(0.5 \%)$, $\mathrm{KH}_{2} \mathrm{PO}_{4}(0.5 \%)$ and $\mathrm{MgSO}_{4}$. Fermentation was carried out on a shaker at 160 RPM for 25 days.

\subsection{Extraction and Isolation}

The culture broth $(21 \mathrm{~L})$ was filtered, and the filtrate was extracted with ethyl acetate $(20 \mathrm{~L} \times 3)$, while the mycelium was extracted three times with $\mathrm{CHCl}_{3}-\mathrm{MeOH}(1: 1)$. The EtOAc layer together with the mycelium extract was concentrated under reduced pressure to give a crude extract $(10 \mathrm{~g})$, and the latter was applied to a silica gel column eluted with a gradient of $\mathrm{CHCl}_{3} / \mathrm{MeOH}(1: 0 \rightarrow 0: 1)$ to obtain five fractions (1-5). Fraction 3 was subjected to Sephadex $\mathrm{LH}-20\left(\mathrm{CHCl}_{3} / \mathrm{MeOH} 1: 1\right)$ to give two subfractions $(3 a-3 b)$. Fraction $3 a$ was separated by semipreparative $\mathrm{HPLC}\left(\mathrm{MeCN} / \mathrm{H}_{2} \mathrm{O}, 1: 9 \rightarrow 2: 8,30 \mathrm{~min}\right)$ to give three mixtures, then purified separately by Sephadex LH$20 \mathrm{CC}$ (acetone) to give $\mathbf{2}(2.1 \mathrm{mg}), \mathbf{4}(2.0 \mathrm{mg})$ and $\mathbf{5}$ $(4.8 \mathrm{mg})$, respectively. In the same way, subfraction $3 \mathrm{~b}$ was purified by semipreparative $\mathrm{HPLC}\left(\mathrm{MeCN} / \mathrm{H}_{2} \mathrm{O}, 1: 9 \rightarrow 2: 8\right.$, $40 \mathrm{~min})$ to yield $\mathbf{1}(3.1 \mathrm{mg})$ and $\mathbf{3}(3.3 \mathrm{mg})$.

\subsection{Guanacastepene P (1)}

Light yellow oil; $[\alpha]_{\mathrm{D}}^{16}-507.0($ c $0.70, \mathrm{MeOH}) ; \mathrm{IR}(\mathrm{KBr})$ $v_{\max } 3444,2925,1632 \mathrm{~cm}^{-1}$; UV (MeOH) $\lambda_{\max }(\log \varepsilon) 307$ (4.16), 206 (4.16); For ${ }^{1} \mathrm{H}(400 \mathrm{MHz})$ and ${ }^{13} \mathrm{C}$ NMR $(150 \mathrm{MHz})$ spectroscopic data $\left(\mathrm{Me}_{2} \mathrm{CO}-d_{6}\right)$, see Tables 1 and 2; positive ion HRESIMS $\mathrm{m} / \mathrm{z} 339.1930$ (calcd for $\left.\mathrm{C}_{20} \mathrm{H}_{28} \mathrm{O}_{3} \mathrm{Na}[\mathrm{M}+\mathrm{Na}]^{+}, 339.1936\right)$.

\subsection{Guanacastepene Q (2)}

Light yellow oil; $[\alpha]_{\mathrm{D}}^{16}-318.3($ c 1.6, $\mathrm{MeOH})$; IR $(\mathrm{KBr})$ $v_{\max } 3433,2963,2925,1669,1627,1409,1152 \mathrm{~cm}^{-1}$; UV $(\mathrm{MeOH}) \lambda_{\max }(\log \varepsilon) 289$ (4.03), 236 (3.87), 203 (3.91); For ${ }^{1} \mathrm{H}(400 \mathrm{MHz})$ and ${ }^{13} \mathrm{C}$ NMR (100 MHz) spectroscopic data $\left(\mathrm{Me}_{2} \mathrm{CO}-d_{6}\right)$, see Tables 1 and 2; positive ion HRESIMS m/z 315.1962 (calcd for $\mathrm{C}_{20} \mathrm{H}_{27} \mathrm{O}_{3}[\mathrm{M}+\mathrm{H}]^{+}$, 315.1960).

\subsection{Guanacastepene R (3)}

Light yellow oil; $[\alpha]_{\mathrm{D}}^{16}-303.7$ (c 1.9, MeOH); IR (KBr) $v_{\max } 3433,2924,1630,1104 \mathrm{~cm}^{-1}$; UV (MeOH) $\lambda_{\max }(\log$ ع) 285 (3.99), 232 (3.82), 203 (3.93); For ${ }^{1} \mathrm{H}$ (400 MHz) and ${ }^{13} \mathrm{C}$ NMR $(150 \mathrm{MHz})$ spectroscopic data $\left(\mathrm{Me}_{2} \mathrm{CO}-d_{6}\right)$, see Tables 1 and 2; positive ion HRESIMS $\mathrm{m} / \mathrm{z} 353.1737$ (calcd for $\mathrm{C}_{20} \mathrm{H}_{26} \mathrm{O}_{4}[\mathrm{M}+\mathrm{H}]^{+}, 353.1728$ ).

\subsection{Guanacastepene S (4)}

Colorless oil; $[\alpha]_{\mathrm{D}}^{21}-167.5\left(\right.$ c 1.9, MeOH); IR (KBr) $v_{\max }$ 3431, 2924, 2346, $1630 \mathrm{~cm}^{-1}$; UV (MeOH) $\lambda_{\max }(\log \varepsilon)$ 285 (3.82), 201 (3.86); For ${ }^{1} \mathrm{H}$ (400 MHz) and ${ }^{13} \mathrm{C}$ NMR 
$(150 \mathrm{MHz})$ spectroscopic data $\left(\mathrm{Me}_{2} \mathrm{CO}-d_{6}\right)$, see Tables 1 and 2; positive ion HRESIMS $\mathrm{m} / \mathrm{z} 339.1927$ (calcd for $\mathrm{C}_{20} \mathrm{H}_{28} \mathrm{O}_{3}[\mathrm{M}+\mathrm{Na}]^{+}$, 339.1927).

\subsection{Guanacastepene T (5)}

Colorless oil; $[\alpha]_{\mathrm{D}}^{21}+0.75($ c $0.8, \mathrm{MeOH}) ; \mathrm{IR}(\mathrm{KBr}) v_{\max }$ 3440, 2923, $1631 \mathrm{~cm}^{-1}$; UV (MeOH) $\lambda_{\max }(\log \varepsilon) 252$ (3.71), 201(3.52); For ${ }^{1} \mathrm{H}(400 \mathrm{MHz})$ and ${ }^{13} \mathrm{C}$ NMR $(150 \mathrm{MHz})$ spectroscopic data $\left(\mathrm{CDCl}_{3}\right)$, see Tables 1 and 2; positive ion HRESIMS $\mathrm{m} / \mathrm{z} 341.2091$ (calcd for $\left.\mathrm{C}_{20} \mathrm{H}_{30} \mathrm{O}_{3}[\mathrm{M}+\mathrm{Na}]^{+}, 341.2092\right)$.

\subsection{Cytotoxicity Assay}

Human myeloid leukemia HL-60, hepatocellular carcinoma SMMC-7721, lung cancer A-549 cells, breast cancer MCF-7 and colon cancer SW480 cell lines were used in the cytotoxic assay. All cell lines were cultured in RPMI-1640 or DMEM medium (Hyclone, USA), supplemented with $10 \%$ fetal bovine serum (Hyclone, USA) in $5 \% \mathrm{CO}_{2}$ at 37 ${ }^{\circ} \mathrm{C}$. The cytotoxicity assay was performed according to the MTT [3-(4,5-dimethylthiazol-2-yl)-2,5-diphenyl tetrazolium bromide[ method in 96-well microplates [21]. Briefly, adherent cells $(100 \mu \mathrm{L})$ were seeded into each well of 96-well cell culture plates and allowed to adhere for $12 \mathrm{~h}$ before drug addition, while suspended cells were seeded just before drug addition with initial density of $1 \times 10^{5}$ cells/mL. Each tumor cell line was exposed to the test compound dissolved in DMSO at concentrations of 0.0625, $0.32,1.6,8$, and $40 \mu \mathrm{M}$ in triplicates for $48 \mathrm{~h}$, with cisplatin (Sigma, USA) as a positive control. After compound treatment, cell viability was detected and a cell growth curve was graphed. $\mathrm{IC}_{50}$ values were calculated by Reed and Muench's method [22].

\subsection{Antiviral Assay}

Confluent Vero cells in a 96-well tissue plate were inoculated in triplicate with virus suspension $(50 \mu \mathrm{L})$ [HSV/ Blue, at multiplicity of infection (MOI) 1] and culture medium $(50 \mu \mathrm{L})$ containing testing compounds at different concentrations. Cells were lysed with $1 \%$ Nonidet P-40 in DMEM at $24 \mathrm{~h}$ postinfection. Lysates from each well were mixed with chlorophenol red- $\beta$-D-galactopyranoside [CPRG; Boehringer, Ingelheim, Germany), and $\beta$-galactosidase ( $\beta$-Gal)] activity was measured by taking absorbance readings at $570 \mathrm{~nm}$ every $2 \mathrm{~min}$ for a total of 25 readings. The slope of the line was used to quantify $\beta$-Gal activity as milli-optical density units/min (mOD/min). The $50 \%$ inhibitory concentration $\left(\mathrm{IC}_{50}\right)$ was defined as the concentration of the antiviral drug that reduced the $\mathrm{mOD} / \mathrm{min}$ values by $50 \%$ relative to the virus control. Inhibitory concentrations were calculated using the probit regression method [23].

\subsection{Inhibitory Activities Against 11 $\beta$-HSD1 Assay}

Inhibitory activities of the compounds on human or mouse $11 \beta$-HSD1 were determined using scintillation proximity assay (SPA). Microsomes containing $11 \beta$-HSD1 were used according to our previous studies [24, 25]. Full-length cDNAs of human or murine $11 \beta$-HSD1 were isolated from cDNA libraries provided by the NIH Mammalian Gene Collection. The cDNAs were cloned into pcDNA3 expression vectors. HEK-293 cells were transfected with the pcDNA3-derived expression plasmid and selected by cultivation in the presence of G418 $(700 \mu \mathrm{g} / \mathrm{mL})$. The microsomal fraction overexpressing $11 \beta$-HSD1 was prepared from the HEK-293 cells, which were stable transfected with $11 \beta$-HSD1. The fraction was then used as the enzyme source for SPA. Microsomes containing human or mouse $11 \beta$-HSD1 were incubated with NADPH and $\left[{ }^{3} \mathrm{H}\right]$ cortisone. The product, $\left[{ }^{3} \mathrm{H}\right]$ cortisol, was specifically captured by a monoclonal antibody coupled to protein A-coated SPA beads. All tests were done in twice with glycyrrhizinic acid as a positive control. $\mathrm{IC}_{50}(\mathrm{X} \pm \mathrm{SD}, n=$ 2) values were calculated by using Prism Version 4 (GraphPad Software, San Diego, CA, USA).

Acknowledgments This project was supported by the National Natural Sciences Foundation of China (U1132607, 81373289).

Conflict of interest All authors declare no conflict of interest.

Open Access This article is distributed under the terms of the Creative Commons Attribution License which permits any use, distribution, and reproduction in any medium, provided the original author(s) and the source are credited.

\section{References}

1. S.F. Brady, M.P. Singh, J.E. Janso, J. Clardy, J. Am. Chem. Soc. 122, 2116-2117 (2000)

2. S.F. Brady, S.M. Bondi, J. Clardy, J. Am. Chem. Soc. 123, 9900-9901 (2001)

3. M. Kettering, C. Valdivia, O. Sterner, H. Anke, E. Thines, J. Antibiot. 58, 390-396 (2005)

4. C. Valdivia, M. Kettering, H. Anke, E. Thines, O. Sterner, Tetrahedron 61, 9527-9532 (2005)

5. Y.X. Qu, Y.Y. Li, X.M. Qian, Y.M. Shen, Phytochemistry 78, 190-196 (2012)

6. M.A. Battiste, P.M. Pelphrey, D.L. Wright, Chemistry 12, 3438-3447 (2006)

7. K.M. Brummond, D. Gao, Org. Lett. 5, 3491-3494 (2003)

8. X.H. Du, H.V. Chu, O. Kwon, Org. Lett. 5, 1923-1926 (2003) 
9. G.B. Dudley, D.S. Tan, G. Kim, J.M. Tanski, S.J. Danishefsky, Tetrahedron Lett. 42, 6789-6791 (2001)

10. G.B. Dudley, S.J. Danishefsky, Org. Lett. 3, 2399-2402 (2001)

11. C.M. Gampe, E.M. Carreira, Angew. Chem. Int. Ed. 50, 2962-2965 (2011)

12. C.C. Hughes, J.J. Kennedy-Smith, D. Trauner, Org. Lett. 5, 4113-4115 (2003)

13. C.C. Hughes, A.K. Miller, D. Trauner, Org. Lett. 7, 3425-3428 (2005)

14. C.C. Li, C.H. Wang, B. Liang, X.H. Zhang, L.J. Deng, S. Liang, J.H. Chen, Y.D. Wu, Z. Yang, J. Org. Chem. 71, 6892-6897 (2006)

15. S.N. Lin, G.B. Dudley, D.S. Tan, S.J. Danishefsky, Angew. Chem. Int. Ed. 41, 2188-2191 (2002)

16. C.A. McGowan, A.K. Schmieder, L. Roberts, M.F. Greaney, Org. Biomol. Chem. 5, 1522-1524 (2007)
17. G. Mehta, J.D. Umarye, Org. Lett. 4, 1063-1066 (2002)

18. Y. Oonishi, A. Taniuchi, Y. Sato, Synthesis 28, 84-2892 (2010)

19. S. Iimura, L.E. Overman, R. Paulini, A. Zakarian, J. Am. Chem. Soc. 128, 13095-13101 (2006)

20. M.P. Singh, J.E. Janso, S.W. Luckman, S.F. Brady, J. Clardy, M. Greenstein, W.M.J. Maiese, J. Antibiot. 53, 256-261 (2000)

21. T. Mosmann, J. Immunol. Methods 65, 55-63 (1983)

22. L.J. Reed, H. Muench, Am. J. Hyg. 27, 493-497 (1938)

23. Q.C. Zhu, Y. Wang, T. Peng, J. Biomol. Screen. 15, 1016-1020 (2010)

24. H.Y. Yang, W. Dou, J. Lou, Y. Leng, J.H. Shen, J Bioorg. Med. Chem. Lett. 18, 1340-1345 (2008)

25. H.Y. Yang, Y. Shen, J.H. Chen, Q.F. Jiang, Y. Leng, J.H. Shen, Eur. J. Med. Chem. 44, 1167-1171 (2009) 